Editon Consortium Publishing

Transforming Scholarly Publishing
Editon Consortium Journal of Arts, Humanities and Social Studies (ECJAHSS)

Volume: 01 Issue: 01 | April -2019

ISSN: $2663-8525$ www.editoncpublishing.org

Ooga, E. M \& Ekwenye, J., Editon Cons. J. Kiswahili., Double -Blind Peer Reviewed Journal

\title{
Current Established Structures That Run SDA Church Programs in Nakuru East and West Sub-Counties
}

\author{
Evans Mong'are Ooga ${ }^{1}$, John Ekwenye ${ }^{2}$ \\ 1, 2: Adventist University of Africa
}

\begin{abstract}
:
Spiritual growth and development of the Seventh-day Adventist church are significant in its life. It is important that the church fulfils its mandate of reaching people with the gospel and retain those who have already believed. While there is generally a growth in membership in the Adventist church in Africa, this is not the case in the Seventh-day Adventist churches in East and West Sub-counties in Nakuru County, Kenya. This study examined the currently established structures that run SDA church programs in Nakuru East and West Subcounties. The researcher employed descriptive research designs with both qualitative and quantitative research methods. The results indicated that believers indeed had spiritual challenges that hindered the church from growing. It was found out that with commitment and education in the word of God members have the potential to reach the masses with the word of God. The findings from the study indicate that the Sabbath school and afternoon programs were poorly attended. It was also observed that family life becomes very repulsive because it touched on the personal lives of Members. It has been observed that though structures are in place, there is difficulty in fulfilling the programs on time. The leaders of the churches in this locality will need to work together with the laity in addressing the spiritual challenges. When they work together results be a religious people and a church ready to fulfil God's mission. The spiritual leaders need to take a front lead. In addition, departmental leaders in the church should design spiritual programs that are vibrant and that are inclusive encourage the participation of all members.
\end{abstract}

Key Words: Established Structures, Run, SDA Church Programs

$* * *$

How to cite this article in APA ( $6^{\text {th }}$ Edition)

Ooga, E. M \& Ekwenye, J. (2019). Current Established Structures That Run SDA Church Programs in Nakuru East and West Sub-Counties. Editon Cons. J. Arts., Humanit. S. Stud., 1(1), 32-

39.

$* * *$ 


\section{Editon Consortium Journal of Arts, Humanities and Social Studies (ECJAHSS)}

Volume: 01 Issue: 01 | April -2019

ISSN: $2663-8525$

www.editoncpublishing.org

Ooga, E. M \& Ekwenye, J., Editon Cons. J. Kiswahili., Double -Blind Peer Reviewed Journal

\section{Introduction}

In any institution, growth is the core goal and the same is true of the Seventh-day Adventist church. Real growth in the church takes place when laypeople are passionate about the mission of Jesus Christ and very active in sharing His love. The researcher accepts the fact that Adventism in Africa is generally growing numerically unlike in Nakuru East and West sub-counties, churches' growth is minimal both in membership, evangelism, and infrastructure and even witnessing. There are fears that levels of commitment in terms of participation in church activities including financial obligation could be the reason for declining membership. The conference statistics indicate that the whole conference for three years that is 2014 to April 2016 had only increased by 4880 members (see the attached Appendix A). When one probes these figures coming from a total of 497 churches will translate to every church in those three years adding only at most ten new members, hence a worrying trend of the commitment of the members on exponential growth.

The mandate of the Seventh-day Adventist Church is to ensure that its members are spiritual and to win many others to the kingdom of God. In trying to achieve its mission the Nakuru East and West sub-counties representative sample of the Nakuru County churches face a lot of challenges that include retention of new converts and members' involvement in evangelism programmes. The research, therefore, sought to establish challenges facing spiritual growth and development in this locality, and find out strategies to address the challenges for the church to fulfil its mandate.

\section{Church Administration}

The way the church runs administratively determines how successful she can be. Church leaders have the responsibility to show the spiritual direction that members need to follow. The greatest challenge now is that church administration has been secularised. Leaders neglect the leading of the Holy Spirit and engage in politics even at church elections. Divisions and conflicts are becoming a norm just because the church has closed out the leading of the Holy Spirit. In the book, God, Man and Church Growth by A. R. Tippett indicates, "The Holy Spirit guided the early church in matters of administration. Commenting on the momentous decision made at the first council in Jerusalem, Peter declared; "it has seemed good to the Holy Spirit and to us... (15:28)." When Paul was admonishing the elders of the Ephesian church, he solemnly reminded them that the Holy Spirit Himself had made them guardians of the flock (20:28) (Tippett, 1973).

It is very crucial for members to know when the Spirit of the Lord is leading. Members need the assurance that God calls their leaders. Santrac notes that "People who cannot have confidence in their leaders tend to be a scattered flock without a shepherd, and this leads to spiritual disaster (Santrac, 2011). To remove any wrangles in leadership then leaders must be led by the Holy Spirit. When the early church allowed the leading of the Holy Spirit growth was experienced. A careful study of the early church would indicate that the believers who were baptized continued daily in the apostle's doctrine, prayer and worship, "the Lord added to their number day by day those who were being saved (Acts 2: 47)." In a little while, the original three thousand members had increased to five thousand (4:4). When work was too much for the apostles and time came to elect the first deacons of the church at Jerusalem, the apostle's insisted that among other qualifications, they should be men "full of the Holy Spirit (6:1-7)." When church administration is right, it can greatly enhance the spiritual growth of the members. In their book Missiology, Terry indicates that "vital sign number one of a healthy church is a pastor who is a possibility thinker and whose dynamic leadership has been used to catalyse the entire church into action for growth (Terry et al., 1998) 


\section{Editon Consortium Journal of Arts, Humanities and Social Studies (ECJAHSS)}

Volume: 01 Issue: 01 | April -2019

ISSN: 2663-8525

www.editoncpublishing.org

Ooga, E. M \& Ekwenye, J., Editon Cons. J. Kiswahili., Double -Blind Peer Reviewed Journal

The role of the church leadership is such important that the growth of the church depends upon them. The leaders need to understand that they are handling spiritual matters and heed to Gods command by being holy. Joe E. Trull and James E. Carter in their book Ministerial Ethics: Moral Formation for Church Leaders points out, "In handling spiritual things regularly, ministers can quickly become too familiar with the holy. The spiritual disciplines and exercises they teach others may become apathetic to them. A severe ethical issue arises when ministers require of others what they do not practice themselves or what they practice so routinely that the act loses all meaning (Trull \& Carter, 2004). The church can easily overcome spiritual decline when the pastors and elders seriously overcome handling spiritual issues like mere secular matters. The pastors need to remember that as leaders of the church, the followers are watching them and it is not easily possible for the believers to go beyond their spiritual maturity. The far that they have gone as spiritual leaders is the far the members of the church can go.

If something needs to be seriously guarded and cherished by the ministers of the gospel, then it is their spiritual wellbeing. Trull and Carter further indicate, "Education does not end with the seminary. Learning about the Bible, God, and the relationship between God and humankind is a lifelong activity. As life unfolds and one encounters new life experiences, one's understanding of God and spiritual matters should grow (Trull \& Carter, 2004).The things and disciplines that make a minister truly one and those things that will make Christians grow in their spirituality are not hidden. Spiritual growth comes from the regular practice of prayer, Bible study, worship, and Christian service.

Neglecting spiritual growth for the pastor will not only affect him as a person, but knowingly or unknowingly it will affect the congregation also. Bobby Moore in Ministry: International Journal for Pastors in His article, "Making Space for God: Contemplation as Praxis," reveals "If pastors do not, with some forthright intentionality, make a concerted effort to nurture their own spirituality, sooner or later they will discover that the emptiness of their spiritual life is mirrored in the lives of the congregation and they no longer have a passion for ministry. Nor are they equipped to have an effective ministry (Moore, 2009). This is why the role of the pastor and elder in a local church is of uttermost importance. The researcher contends therefore that the challenges facing spiritual growth of the churches in the locality of the study was partly contributed by the lack of pastors and elders who are spiritually mature and strong. Men and women who have an existing relationship with the Jesus Christ, and who daily draw from Him every energy, wisdom and everything needed to direct the church of God. Moore stipulates that "We can through faith and grace, become like Christ by practising the types and activities he engaged in, by arranging our whole lives around the events to remain always at home in the fellowship of his Father (Moore, 2009). The leaders, therefore, have a standard to which they must attain, and the standard is Jesus Christ.

Growth does not just happen; it has to follow through all the plans into implementation. The SDA church in South America today has one of the highest rates of numerical growth and geographical expansion in all of Adventism. Alberto R. Timm mentions in Ministry, "Building a Growing Church: The South American Experience," "Some may imagine that the growth expansion of the Adventist Church in South America comes naturally from preaching to a receptive population. Undoubtedly, that region can be classified as much more open as to the gospel message than some other parts of the world. Instead of being just an accident, that positive experience built across time through many efforts and ongoing methodological experiments (Timm, 2008). It is important to understand God's vision for churches. The vision of leadership for a church must come directly and specifically from God. 
Editon Consortium Publishing

Transforming Scholarly Publishing

\section{Editon Consortium Journal of Arts, Humanities and Social Studies (ECJAHSS)}

Volume: 01 Issue: 01 | April -2019

ISSN: $2663-8525$

www.editoncpublishing.org

Ooga, E. M \& Ekwenye, J., Editon Cons. J. Kiswahili., Double -Blind Peer Reviewed Journal

\section{Methodology}

This study was based on mixed methods of research design. It utilised both qualitative and quantitative methods of research. The researcher employed a qualitative approach in the form of structured and semistructured questions to include the respondents' views and opinions concerning the study as the situation were in the time of the study. The quantitative research approach was used in the form of structured questions (closed-ended questions) in a five Likert scale as the study included numbers. This helped the researcher to obtain a clear picture of the situation from the respondents concerning the topic under study. The descriptive research design was used since it measured the overall descriptions of situations or phenomenon in a systematic way conceptualising the reality in terms of variables. It also investigated the current status and nature of the phenomenon under the study. Integration of these methods facilitated the extraction of as much information and data as possible through SPSS (Statistical Package of Social Sciences).

The population of the study comprised of 220 church board members from the ten selected churches in Nakuru East and West sub-Counties. These churches include Crater, Nakuru central (Bondeni), Great News, Racetrack and Langalanga from Nakuru East Sub-County. Others were Nakuru West, Kaptembwa Angaza, Abundant life, Kiamunyi East and California from Nakuru West Sub-County. These target population of churches are found within the range of $1-10 \mathrm{~km}$ apart. The population is as presented in Table 2 below.

\begin{tabular}{|l|l|l|}
\hline Church & Population & $\begin{array}{l}\text { Target } \\
\text { Church } \\
\text { members }\end{array}$ \\
\hline Crater & 575 & 29 \\
\hline $\begin{array}{l}\text { Nakuru } \\
\text { Central }\end{array}$ & 577 & 25 \\
\hline Great News & 324 & 19 \\
\hline Langalanga & 287 & 17 \\
\hline Racetrack & 141 & 17 \\
\hline $\begin{array}{l}\text { Nakuru } \\
\text { West }\end{array}$ & 1407 & 37 \\
\hline $\begin{array}{l}\text { Kaptembwa } \\
\text { Angaza }\end{array}$ & 505 & 23 \\
\hline $\begin{array}{l}\text { Abundant } \\
\text { life }\end{array}$ & 225 & 19 \\
\hline $\begin{array}{l}\text { Kiamunyi } \\
\text { East }\end{array}$ & 230 & 17 \\
\hline California & 117 & 17 \\
\hline TOTAL & 4388 & 220 \\
\hline
\end{tabular}

Table 1. The Population and Sample Size

The researcher purposively targeted all church board members from the 10 selected churches. This was because church board members are mandated to oversee the spiritual growth and development of the churches (General Conference of Seventh-day Adventists, 2010). The statistics were gathered from the church board minute book as shown and presented in table 2 above. The researcher also accessed seven pastors from those churches who acted as key informants of the study. This sample was used to determine the sample that represented members from various areas and also ensured that each unit of the population got equal chances of being represented in all groups.

The sample size is the portion of the population which represents the total population under study, and as the 
Editon Consortium Publishing

Transforming Scholarly Publishing

\section{Editon Consortium Journal of Arts, Humanities and Social Studies (ECJAHSS)}

Volume: 01 Issue: 01 | April -2019

ISSN: $2663-8525$

www.editoncpublishing.org

Ooga, E. M \& Ekwenye, J., Editon Cons. J. Kiswahili., Double -Blind Peer Reviewed Journal

sample was properly selected, the information collected would be used to make statements on the whole population. According to Morgan, a formula for determining sample size calculation as seen in the table in the appendices, the sample size of the total target population (220) was 137respondents. The proportionate allocation sampling formula was used to obtain the correct sample size of members in each cluster (church) in collaboration with the sample size of the target population derived by Morgan.

$\mathrm{ni}=\mathrm{n} \times \mathrm{nj}$

$\mathrm{ni}=$ Sample size of the cluster (church).

$\mathrm{n}=$ Sample size of target population derived by Morgan

$\mathrm{nj}=$ Population of each cluster (church)

$\mathrm{N}=$ Target population

Table 2 Showing Sample Size

\begin{tabular}{|l|l|l|l|}
\hline Church & Population & $\begin{array}{l}\text { Target } \\
\text { Population } \\
\text { (Church board } \\
\text { members) }\end{array}$ & $\begin{array}{l}\text { Sample } \\
\text { size }\end{array}$ \\
\hline Crater & 575 & 29 & 18 \\
\hline $\begin{array}{l}\text { Nakuru } \\
\text { Central }\end{array}$ & 577 & 25 & 15 \\
\hline Great News & 324 & 19 & 12 \\
\hline Langalanga & 287 & 17 & 11 \\
\hline Racetrack & 141 & 17 & 11 \\
\hline Nakuru West & 1407 & 37 & 23 \\
\hline $\begin{array}{l}\text { Kaptembwa } \\
\text { Angaza }\end{array}$ & 505 & 23 & 15 \\
\hline Abundant life & 225 & 19 & 12 \\
\hline Kiamunyi East & 230 & 17 & 11 \\
\hline California & 117 & 17 & 11 \\
\hline & 4388 & $\mathbf{2 2 0}$ & $\mathbf{1 3 7}$ \\
\hline
\end{tabular}

An interview guide was constructed and administered in the form of self-administered questionnaires. The nature of the questions was discussed with the sampled members of the church boards from selected churches. It was explained to them why the researcher targeted them, that they hold a significant place in the church as a spiritual guardian and sought for their cooperation. The questionnaires were constructed and administered. The nature of the questions were in the form of structured and close-ended questions whereby a 5 Likert scale of measurement was used on closed-ended items as illustrated: The instruments of research were divided into three sections: $A, B$ and $C$. Section $A$ dealt with demographic background on issues such as gender, age, county and years in Adventism. Section B comprised of variables of church structures and Programs while section $C$ was an interview guide where church board members gave their opinions.

Table 3 Likert Scale Coding Interpretation

\begin{tabular}{|l|l|l|l|}
\hline Description & $\begin{array}{l}\text { Mean } \\
\text { Range }\end{array}$ & $\begin{array}{l}\text { Scale } \\
\text { Coding }\end{array}$ & Interpretation \\
\hline Strongly Agree & $\begin{array}{l}4.20- \\
5.00\end{array}$ & 5 & Very high \\
\hline Agree & $\begin{array}{l}3.40- \\
4.19\end{array}$ & 4 & High \\
\hline At times & $\begin{array}{l}2.60- \\
3.39\end{array}$ & 3 & Moderate \\
\hline Disagree & $1.80-2.59$ & 2 & Low \\
\hline Strongly & $1.00-$ & 1 & Very low \\
Disagree & 1.79 & & \\
\hline
\end{tabular}

After the data collection, the raw data was fed into the computer to analyse it through the statistical package for social sciences (SPSS). The data collected from the interview guide were analysed using coding through themes to back up the primary data. The quantitative data that could not be coded was synthesised with critical analysis and back up of the primary data. Response patterns were categorised into meaningful units or segments. The codes were used to construct and interpret 
Editon Consortium Publishing

Transforming Scholarly Publishing

\section{Editon Consortium Journal of Arts, Humanities and Social Studies (ECJAHSS)}

Volume: 01 Issue: 01 | April -2019

ISSN: $2663-8525$ www.editoncpublishing.org

Ooga, E. M \& Ekwenye, J., Editon Cons. J. Kiswahili., Double -Blind Peer Reviewed Journal

common themes or patterns. Data from other sources were recorded manually in field diary and notebooks were systematically coded and analysed. Recurrent and emerging themes were identified and organised into meaning full categories and subcategories. Some quotations were extracted and presented in verbatim. For comprehensiveness, data from the different data collections techniques were triangulated to validate and complement the findings from each of the sources.

\section{Results}

The study sought to determine the currently established structures that run church programs in Nakuru East and West sub-counties; the findings are as shown in the chart that follows.

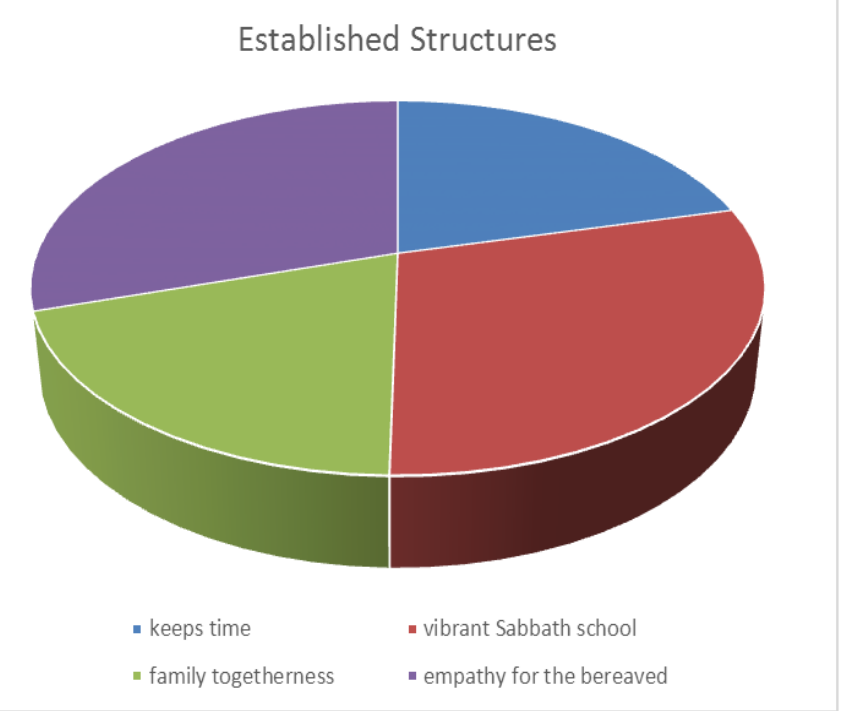

Figure 2 chart showing Established Structures

On matters of punctuality and proper time management in programs, an average of $71(51.8 \%)$ agreed that church programs were conducted at a scheduled time although $66(48.2 \%)$ refuted this fact. The findings indicate that in some churches within Nakuru East and West sub-counties, programs were moderately well despite some churches which took too long in their programs hence discouraging members from attending regularly.

Concerning the Sabbath school, a majority of 99(72.3\%) agreed that the morning services were lively and exciting as compared to $38(27.7 \%)$ who found Sabbath school programs dull and tiresome. From the respondent's views and opinions the Sabbath school was rated last as program members attended to. The Sabbath school allows members to learn and understand the Bible truths as presented in the study guide.

The Sabbath school seems to be playing an important role in spiritual growth. The Sabbath School Department of the General Conference emphasises four areas of focus for each adult Sabbath School: "fellowship, community outreach, Bible study, and missions (General Conference of Seventh-day Adventists, 2010).

On churches having the program of family togetherness, a slightly low average of $67(48.9 \%)$ agreed that their church had the program of intimate family attachment as compared to a majority of $70(51.1 \%)$ who differed from the statement. The results implied that most members in churches had no meaningful family devotions and oneness an occurrence which may have led them into low spiritual vibrancy and development. Related to this is the fact that family life is recognised as an essential segment in the lives of members.

On the church empathy to the bereaved and needy, $101(73.7 \%)$ agreed that the church made a generous contribution to people who had lost their loved ones. Despite this, a marginal population of $36(26.3 \%)$ disagreed with the idea. This indicated that most members in the churches were driven by Christian empathy and contributed towards uplifting their neighbours, friends, church members among others who were faced by the challenges of grief and mourning. Bereavement refers to 


\section{Editon Consortium Journal of Arts, Humanities and Social Studies (ECJAHSS)}

Volume: 01 Issue: 01 | April -2019

ISSN: 2663-8525

www.editoncpublishing.org

Ooga, E. M \& Ekwenye, J., Editon Cons. J. Kiswahili., Double -Blind Peer Reviewed Journal

the objective situation of an individual who has recently experienced the loss of someone significant through that person's death. Stroebe states that "Bereavement is the cause of both grief and mourning. Grief is the emotional (affective) response to loss, which includes several psychological and somatic reactions. It has been defined as an emotional syndrome (Averill, 1979; Lindemann, 1944), that is, a set of responses co-varying systematically (Stroebe \& Wolfgang, 1987) While some responses may be more symptomatic of grief than others, no single response is essential to the syndrome. "Mourning refers to the acts expressive of grief. These acts are shared by the mourning practices of a given society or cultural group, which serve as guidelines for how bereaved persons are expected to behave (Stroebe \& Wolfgang, 1987).

However, the most central idea is the fact that bereaved families and members in the church deserve comfort and care. The church, therefore, has a significant role to play in comforting the bereaved families. Following the work of Wuthnow et al., Pargament et al. focused on the individual's capacity to face stressful life events, observing that religious individuals tended to include religion in their cognitive constructions of the bereavement experience, particularly when they realised their shortcomings in managing the challenges of the situation. Furthermore, people who search for meaning through religion, often have faith as both an end and a means in their adjustment process following bereavement (Hays \& Hendrix, 2008). There is no uniform mourning practice or guidelines for meaning-making within Christianity; it all depends on the context and cultural traditions of the bereaved. The coping strategies of an individual are influenced by theological, liturgical and social factors (Hays \& Hendrix, 2008).

Relating to membership participation, a majority of three quarters thus 99(72.3\%) agreed that they participate fully in church programs, as compared to a quarter thus 38(27.7\%) who were not entangled more in fellowship involvement.
The outcome indicates that members in Nakuru SubCounties felt secure in church, they owned church programs and felt as part and parcel in fellowship plans, although others were not.

From the opinions and views on church programs that were found disgusting, the estimates of many respondents indicated that there were very few disgusting programs. Programs such as family life, afternoon programs, church promotion and contribution of money towards some development projects, and family life were viewed as some of the disgusting programs. The respondents observed that family life becomes very repulsive because it touches on their personal lives. When asked what they usually did, many responded that they do nothing other than cooperate with the leadership and submit to the authority.

The members opined that the best programs to be organised for the youths should be geared on drug and substance abuse, post-modernism, organised outings, youth congresses and seminars among others should be introduced. On the same note they suggested that to change the attitudes of parents towards family life, programs such as Youth parents forum, symposiums, organised discussions among others will be very helpful. On the same note, suggestions indicated that to improve important programs such as Sabbath School; the sessions should have short music, have competent teachers, as well as having attractive and exciting programs, while on Divine Service there should be vibrant speakers, interactive, informed and well knowledgeable and informed. The preacher should also be brief and precise.

\section{Conclusion}

The findings from the study indicate that the Sabbath school and afternoon programs were poorly attended. It was also observed that family life becomes very repulsive because it touched on the personal lives of Members. It has 
Editon Consortium Publishing

Transforming Scholarly Publishing

\section{Editon Consortium Journal of Arts, Humanities and Social Studies (ECJAHSS)}

Volume: 01 Issue: 01 | April -2019

ISSN: $2663-8525$ www.editoncpublishing.org

Ooga, E. M \& Ekwenye, J., Editon Cons. J. Kiswahili., Double -Blind Peer Reviewed Journal

been observed that though structures are in place, there is difficulty in fulfilling the programs on time.

\section{Recommendations}

Departmental leaders in the church should design spiritual programs that are vibrant and that are inclusive to encourage the participation of all members.

\section{REFERENCES}

General Conference of Seventh-day Adventists, (2010). Seventh-day Adventist Church Manual. Silver Spring, MD: General Conference of Seventh-day Adventists.

Hays, J. \& Cristina H. (2008). The Role of Religion in Bereavement. Virginia Commonwealth University.

Moore, B. (2009). Making Space for God: Contemplation as Praxis. Ministry: International Journal of Pastors, 6-9.

Santrac, A. S. (2011). Spiritual Strength: What Happens when Spiritual Leaders and Spiritual People work Together? Ministry: International Journal of Pastors 1(5): 21-23.

Stroebe, W. \& Stroebe S. (1987). Bereavement and Health: The Psychological and Physical Consequences of Partner Loss. Cambridge University Press.

Terry, J. M., Ebbie S., \& Justice A. (1998). Missiology: An Introduction to the Foundations, History and Strategies of World Missions. Nashville: Broadman and Holman Publishers.

Timm, A. R. (2008). Building a Growing Church: The South American Experience, Ministry: International Journal of Pastors, 20-23.

Tippet, A. R. (1973). God, Man, and Church Growth. Grand Rapids MI: W. M. B. Eerdmans,

Trull, J. E. \&. Carter. J. E. (2004). Ministerial Ethics: Moral Formation for Church Leaders. Grand Rapids MI: Baker Academic. 